\title{
HYPERSPECTRAL FIELD REFLECTANCE MEASUREMENTS TO ESTIMATE WHEAT GRAIN YIELD AND PLANT HEIGHT
}

\author{
Alexandre Cândido Xavier ${ }^{1}$; Bernardo Friedrich Theodor Rudorff ${ }^{2 *}$; Mauricio Alves Moreira²; \\ Brummer Seda Alvarenga²; José Guilherme de Freitas ${ }^{3}$; Marcus Vinicius Salomon ${ }^{3}$ \\ ${ }^{1}$ Universidade Federal do Espirito Santo - UFES, C.P. 16 - 29500-000 - Alegre, ES - Brasil. \\ ${ }^{2}$ Instituto Nacional de Pesquisas Espaciais - INPE, C.P. 515 - 12201-970 - São José dos Campos, SP - Brasil. \\ ${ }^{3}$ Instituto Agronômico Campinas - IAC, C.P. 28 - 13020-902 - Campinas, SP - Brasil. \\ *Corresponding author < bernardo@dsrinpe.br>
}

\begin{abstract}
Hyperspectral crop reflectance data are useful for several remote sensing applications in agriculture, but there is still a need for studies to define optimal wavebands to estimate crop biophysical parameters. The objective of this work is to analyze the use of narrow and broad band vegetation indices (VI) derived from hyperspectral field reflectance measurements to estimate wheat (Triticum aestivum L.) grain yield and plant height. A field study was conducted during the winter growing season of 2003 in Campinas, São Paulo State, Brazil. Field canopy reflectance measurements were acquired at six wheat growth stages over 80 plots with four wheat cultivars (IAC-362, IAC-364, IAC-370, and IAC$373)$, five levels of nitrogen fertilizer $\left(0,30,60,90\right.$, and $120 \mathrm{~kg}$ of $\left.\mathrm{N} \mathrm{ha}^{-1}\right)$ and four replicates. The following VI were analyzed: a) hyperspectral or narrow-band VI (1. optimum $m$ ultiple $n$ arrow-band reflectance, OMNBR; 2 . narrow- $b$ and $n$ ormalized $d$ ifference vegetation index, NB_NDVI; 3 . first- and second-order derivative of reflectance; and 4. four derivative green vegetation index); and b) broad band VI (simple ratio, SR; normalized difference vegetation index, NDVI; and soil-adjusted vegetation index, SAVI). Hyperspectral indices provided an overall better estimate of biophysical variables when compared to broad band VI. The OMNBR with four bands presented the highest $\mathrm{R}^{2}$ values to estimate both grain yield $\left(\mathrm{R}^{2}=0.74\right.$; Booting and Heading stages $)$ and plant height $\left(\mathrm{R}^{2}=0.68\right.$; Heading stage $)$. Best results to estimate biophysical variables were observed for spectral measurements acquired between Tillering II and Heading stages.
\end{abstract}

Key words: remote sensing, agriculture, vegetation indices

\section{MEDIDAS DE REFLECTÂNCIA HIPERESPECTRAL A CAMPO PARA ESTIMAR PRODUTIVIDADE DE GRÃOS E ALTURA DE PLANTAS DE TRIGO}

\begin{abstract}
RESUMO: Dados hiperespectrais de reflectância de culturas agrícolas são úteis para diversas aplicações e ainda existe a necessidade de estudos para definir as melhores bandas para estimar parâmetros biofísicos de culturas. O objetivo deste trabalho é analisar o uso de índices de vegetação (IV) de bandas estreitas e largas obtidas de medidas de reflectância hiperespectral a campo para estimar a produtividade de grãos e a altura de plantas do trigo (Triticum aestivum L.). Um experimento a campo foi conduzido durante a entre safra de 2003 em Campinas, São Paulo, Brasil. Medidas de reflectância foram adquiridas ao longo de seis estádios da cultura em 80 parcelas (quatro cultivares, cinco níveis de adubação nitrogenada e quatro repetições). Os IV testados foram: a) de banda estreita ou hiperespectrais (1. ótima reflectância de múltiplas bandas estreitas, OMNBR; 2. índice de vegetação da diferença normalizada com banda estreita, NB_NDVI; 3. primeira e segunda derivada da reflectância e; 4. quatro índices de derivadas da vegetação verde) e b) de banda larga (razão simples, SR; índice vegetativo da diferença normalizada, NDVI e; índice vegetativo ajustado para solo, SAVI). Os índices hiperespectrais forneceram melhores estimativas quando comparados às estimativas dos IV de banda larga. $\mathrm{O}$ índice OMNBR com quatro bandas apresentou os maiores valores de $\mathrm{R}^{2}$ para estimar a produtividade de grãos $\left(R^{2}=0,74\right.$; Emborrachamento e Espigamento $)$ e a altura das plantas $\left(R^{2}=\right.$ 0,68; Espigamento). Os melhores resultados foram observados entre os estádios de Perfilhamento II e Espigamento.

Palavras-chave: sensoriamento remoto, agricultura, índices de vegetação
\end{abstract}




\section{INTRODUCTION}

Broad band vegetation indices (VI) are ordinarily used to estimate biophysical parameters that can be incorporated in models to predict evapotranspiration and crop yield (Myneni et al., 1995). These indices are based on both high absorption of visible solar radiation by plant pigments and high scattering of nearinfrared solar radiation by intercellular air spaces in the leaf mesophyll (Gates et al., 1965). The most widely used VI to estimate biomass, leaf area index (LAI) and absorbed photosynthetically active radiation (Asrar et al., 1984, Turner et al., 1999, Xavier \& Vettorazzi, 2004) are Simple Ratio (SR; Jordan, 1969) and Normalized Difference Vegetation Index (NDVI; Rouse et al., 1974). More recently, Huete (1988) developed the Soil-Adjusted Vegetation Index (SAVI) to reduce soil background effects.

With the advancement of hyperspectral radiometers not only for laboratory or field but also for orbital measurements (e.g. Hyperion sensor on board of EO-1; Earth Observation-1, 2003), new methods to analyze spectral reflectance data were developed. For example, spectral derivative analysis of vegetation spectral reflectance measurements appear to be less sensitive to soil background reflectance effects (Demetriades-Shah et al., 1990). Elvidge \& Chen (1995) and Chen et al. (1998) developed several indices from spectral derivative reflectance curves in the red-edge region $(620-795 \mathrm{~nm})$ due to their low sensitivity to soil background variations, when compared to broad band VI. On the other hand, Broge \& Leblanc (2001) found that hyperspectral data are not better than broad band data to estimate LAI values higher than 2.8.

In the present work, wheat spectral reflectance field measurements were analyzed in terms of narrow and broad band vegetation indices to estimate final grain yield and plant height at several growth stages during crop growing season.

\section{MATERIAL AND METHODS}

\section{Experimental Site and Treatments}

A field study was carried out during the win- ter growing season of 2003 in Campinas, São Paulo State, Brazil (22051'47" S; 4704'42" W). The experiment was set up at a $4 \times 5$ factorial scheme, randomized, complete-block design $(n=4)$, and data were submitted to regression analysis to estimate biophysical variables; treatment effects were not analyzed. Treatments were applied to plots with four wheat (Triticum aestivum, L) cultivars (IAC-362, IAC-364, IAC-370 and IAC-373), and five levels of nitrogen fertilizer $(0,30$, 60,90 and $120 \mathrm{~kg}$ of $\mathrm{N} \mathrm{ha}^{-1}$ ). Plots were $3 \mathrm{~m}$ long, 1.2 $\mathrm{m}$ wide and $0.8 \mathrm{~m}$ apart. Wheat was sown in June 2003 in rows spaced $0.15 \mathrm{~m}$ apart, with approximately 80 seeds per linear meter of row. Phosphorus and potassium were applied at a rate of 40 and $90 \mathrm{~kg} \mathrm{ha}^{-1}$, respectively, while boron and zinc were applied at rates of 0.5 and $1.0 \mathrm{~kg} \mathrm{ha}^{-1}$, respectively. All fertilizers were applied at seeding except for nitrogen, which was applied $50 \%$ at seeding and 50\% was topdressed 30 days after plant emergence, according to the nitrogen fertilizer protocol. Irrigation was applied several times during the wheat growing season to supplement seasonal rainfall.

\section{Plant Characteristics}

Final grain yield and plant height were measured at maturity. To eliminate 'edge-effects' a central area of $1.36 \mathrm{~m}^{2}$ was harvested in each plot. Wheat grains were oven-dried at $80^{\circ} \mathrm{C}$ until $13 \%$ humidity was reached (Carneiro et al., 2005). Five plants per plot were used to estimate average final plant height.

\section{Reflectance Measurements}

Field reflectance measurements were performed over 80 wheat plots with the FieldSpec Pro FR spectroradiometer (Analytical Spectral Device Inc., 2003), at six different growth stages, from early vegetative growth until maturation (Table 1). The radiometric measurements were collected under clear-sky conditions between $10 \mathrm{~h} 00$ and $11 \mathrm{~h} 00$, at $1.2 \mathrm{~m}$ above crop canopy, with the $25^{\circ}$ lens allowing $0.22 \mathrm{~m}^{2}$ field of view areas. One spectral reflectance measurement from the most central part of each plot was taken with the FieldSpec Pro FR over the spectral range $400-2,500 \mathrm{~nm}$. These measurements were then used to simulate the narrow-bands and broad-bands from the spectral bands of the Hyperion (Earth Observation-1,

Table 1 - Spectral measurements dates and corresponding wheat growth stages according to Feekes-Large Scale.

\begin{tabular}{llc}
\hline Date of Measurement & \multicolumn{1}{c}{ Growth Stage } & Short Name \\
\hline July 02,2003 & Plants recent emerged with one or more leaves & Tillering I \\
July 23, 2003 & Tillering & Tillering II \\
Aug 13,2003 & Flag leaf just visible & Jointing \\
Aug 24,2003 & One-fourth of head emerged & Booting \\
Sep 19,2003 & Kernel watery ripe & Heading \\
Oct 01,2003 & Approximate physiological maturity & Maturation \\
\hline
\end{tabular}


2003), and Thematic Mapper (Earth Observation Satellite Company, 1985) sensors, respectively. Due to atmospheric radiation absorption, some bands in the spectral ranges 1,350-1,440 nm; 1,790-1,990 nm; and 2,360-2,500 $\mathrm{nm}$ were disconsidered.

\section{Vegetation Indices and Regression Models}

The most widely broad band VI used in this work were:

- Simple Ratio (SR; Jordan, 1969)

$$
\mathrm{SR}=\frac{\mathrm{B} 4}{\mathrm{~B} 3}
$$

- Normalized Difference Vegetation Index (NDVI; Rouse et al., 1974)

$$
\mathrm{NDVI}=\frac{\mathrm{B} 4-\mathrm{B} 3}{\mathrm{~B} 4+\mathrm{B} 3}
$$

- and Soil-Adjusted Vegetation Index (SAVI; Huete, 1988)

$$
\mathrm{SAVI}=(1+\mathrm{L}) \frac{\mathrm{B} 4-\mathrm{B} 3}{\mathrm{~B} 4+\mathrm{B} 3+\mathrm{L}}
$$

where: B3 (630-690 $\mathrm{nm})$ and B4 (760-900 $\mathrm{nm})$ are simulated spectral bands from the Enhanced Thematic Mapper Plus (ETM+) sensor on board of Landsat-7 remote sensing satellite, and $\mathrm{L}$ is a constant value equal to 0.5 applied to minimize soil background effects (Huete, 1988).

The regression models used were:

nomial);

$$
\begin{aligned}
& \mathrm{B}=a_{0}+a_{1} \mathrm{VI} \text { (linear); } \\
& \mathrm{B}=a_{0} \exp ^{a_{1} \mathrm{VI}} \text { (exponential); } \\
& \mathrm{B}=a_{0}+a_{1} \mathrm{VI}+a_{2} \mathrm{VI}^{2}+\ldots+a_{m} \mathrm{VI}^{m} \text { (poly- }
\end{aligned}
$$

where $\mathrm{B}$ is the biophysical dependent variable (wheat grain or plant height); VI is the Vegetation Index independent variable (SR, NDVI or SAVI); $a_{0}$ and $a_{1}$ are the regression parameters; and $m$ is the degree of the model. Polynomial and exponential models were both used to improve estimates of biophysical variables from spectral variables (Turner et al., 1999; Xavier \& Vettorazzi, 2004).

Reflectance data were analyzed using several methods described in the literature: optimum multiple $n$ arrow- $b$ and $r$ eflectivity (OMNBR, Thenkabail et al., 2000; 2004); narrow-band NDVI (NB_NDVI; Thenkabail et al., 2000); best first- and second-order derivative of reflectance (Demetriades-Shah et al., 1990); and green vegetation indices based on derivatives (Chen et al., 1998; Elvidge \& Chen, 1995). The
OMNBR was defined using the MAXR procedure of Statistical Analysis System (SAS) version 6.12 (SAS Institute, 1997) to find the combination of narrow spectral bands that best predicted model biophysical variable (maximized the $\mathrm{R}^{2}$ ) at each wheat growth stage

$$
\mathrm{B}=\sum_{j=1}^{n} a_{j} \mathrm{NB}_{j},
$$

where $\mathrm{B}$ is the biophysical variable; NB is the narrowband reflectance of band $j(j=1, \ldots, n) ; n$ is the number of Hyperion bands; and $a$ is the regression parameter. For 1, 2, 3 and 4 narrow-bands we have, respectively:

$$
\begin{aligned}
& \mathrm{B}=a+a_{1} \mathrm{NB}_{1} ; \\
& \mathrm{B}=a+a_{1} \mathrm{NB}_{1}+a_{2} \mathrm{NB}_{2} ; \\
& \mathrm{B}=a+a_{1} \mathrm{NB}_{1}+a_{2} \mathrm{NB}_{2}+a_{3} \mathrm{NB}_{3} ; \\
& \mathrm{B}=a+a_{1} \mathrm{NB}_{1}+a_{2} \mathrm{NB}_{2}+a_{3} \mathrm{NB}_{3}+a_{4} \mathrm{NB}_{4}
\end{aligned}
$$

The narrow-band NDVI (NB_NDVI) (Thenkabail et al., 2000) is defined as:

$$
\mathrm{NB} \_\mathrm{NDVI}_{i j}=\frac{\mathrm{NB}_{i}-\mathrm{NB}_{j}}{\mathrm{NB}_{i}+\mathrm{NB}_{j}}
$$

where $i$ and $j$ are band numbers from 1 to 242 allowing $242 \times 242=58,564$ combinations of NB_NDVI for each biophysical variable. Regression coefficients $R^{2}$ between all possible narrow-bands and biophysical variables were determinate using a routine developed with MatLab (MatLab-MathWorks, 2002), that verified for each growth stage the two narrow-bands combination that provided highest $\mathrm{R}^{2}$ values.

The best first- and second-order derivatives of reflectance (1_Der and 2_Der) were used to reduce background reflectance influence (Demetriades-Shah et al., 1990) and were computed as:

$$
\begin{aligned}
& \operatorname{NB}^{\prime}\left(\lambda_{i}\right)=\frac{\operatorname{NB}\left(\lambda_{i+1}\right)-\mathrm{NB}\left(\lambda_{i-1}\right)}{\lambda_{i+1}-\lambda_{i-1}} ; \\
& \operatorname{NB}^{\prime \prime}\left(\lambda_{i}\right)=\frac{\mathrm{NB}^{\prime}\left(\lambda_{i+1}\right)-\mathrm{NB}^{\prime}\left(\lambda_{i-1}\right)}{\lambda_{i+1}-\lambda_{i-1}} ;
\end{aligned}
$$

where $\operatorname{NB}^{\prime}\left(\lambda_{i}\right)$ and $\operatorname{NB}^{\prime \prime}\left(\lambda_{i}\right)$ are, respectively, the firstand second-order derivatives at the midpoint of band $i$ ( $i=$ number of narrow-bands). Highest $\mathrm{R}^{2}$ values for first- and second-order derivatives were determinated using a linear regression model:

$$
\begin{aligned}
& \mathrm{B}=a+a_{1} \mathrm{NB}^{\prime}\left(\lambda_{i}\right) ; \\
& \mathrm{B}=a+a_{1} \mathrm{NB}^{\prime \prime}\left(\lambda_{i}\right) .
\end{aligned}
$$

To generate the derivative green vegetation indices (1DL_DGVI, 1DZ_DGVI, 1DL_MDGVI and 
2DZ_DGVI), the first- and second-order derivatives of reflectance were integrated to calculate the area between the wavelengths of $630 \mathrm{~nm}$ and $793 \mathrm{~nm}$ (Elvidge \& Chen, 1995; Chen et al., 1998):

$$
\begin{aligned}
& 1 \mathrm{DL} \_\mathrm{DGVI}=\sum_{\lambda_{1}}^{\lambda_{n}}\left|\mathrm{NB}^{\prime}\left(\lambda_{i}\right)-\mathrm{NB}^{\prime}\left(\lambda_{1}\right)\right| \Delta \lambda ; \\
& 1 \mathrm{DZ} \_\mathrm{DGVI}=\sum_{\lambda_{1}}^{\lambda_{n}}\left|\operatorname{NB}^{\prime}\left(\lambda_{i}\right)\right| \Delta \lambda ; \\
& 1 \mathrm{DL} \_\mathrm{MDGVI}=\sum_{\lambda_{1}}^{\lambda_{n}}\left|\operatorname{NB}^{\prime}\left(\lambda_{i}\right)-\mathrm{NB}^{\prime}\left(\lambda_{1}\right)\right| \Delta \lambda,
\end{aligned}
$$

where $\mathrm{NB}^{\prime}\left(\lambda_{i}\right)-\mathrm{NB}^{\prime}\left(\lambda_{1}\right)>0$;

$$
2 \mathrm{DZ} \_\mathrm{DGVI}=\sum_{\lambda_{1}}^{\lambda_{n}}\left|\operatorname{NB}^{\prime \prime}\left(\lambda_{i}\right)\right| \Delta \lambda
$$

where $\lambda_{l}$ and $\lambda_{n}$ are the first $(\lambda=630 \mathrm{~nm})$ and last $(\lambda$ $=793 \mathrm{~nm}$ ) narrow-bands to be integrated, respectively. The difference among the derivative green vegetation indices is the base line used as reference in the integration. For 1DL_DGVI, the reference used is the soil base line that considers the value of the first-order derivative at $630 \mathrm{~nm}, \mathrm{NB}^{\prime}\left(\lambda_{1}\right)$; for $1 \mathrm{DZ}$ DGVI, the base line is zero; and for 1DL MDGVI, the reference is also the soil base line, but the computed area is limited for values where the first-order derived is higher than the soil base line. Subtraction of the local derivative base line removes the portion of the red and near-infrared slop effect of the background, improving the vegetation index (Elvidge \& Chen, 1995). The next step consisted to obtain the regression coefficients $\left(\mathrm{R}^{2}\right)$ between these indices and the biophysical variables using linear regression models.

\section{RESULTS AND DISCUSSION}

Wheat grain yield and final plant height ranged from $1,628 \mathrm{~kg} \mathrm{ha}^{-1}$ to $5,593 \mathrm{~kg} \mathrm{ha}^{-1}$, and from $58 \mathrm{~cm}$ to $97 \mathrm{~cm}$, respectively. The relatively large variation observed in these data is mainly attributed to different $\mathrm{N}$ treatments and to some extent to differences among genetic material. Moreira et al. (2005) studied spectral reflectance variation among 20 wheat genotypes, and registered that spectral reflectances and final biomass weight, for three of the genotypes used in the present work (IAC 364, IAC 370 and IAC 373), were quite similar. Also, significant improvements in $\mathrm{R}^{2}$ values were not observed for regressions performed by cultivar; therefore, regression analysis was performed by pooling genotypes.

Correlation coefficient between grain yield and plant height was 0.50 . Figure 1 indicates that data asymmetry was not observed.
Figure 2 shows the average spectral reflectance behavior at each growth stage for the 80 plots. Spectral variations among curves are mainly due to differences in crop growth stages. Lowest reflectance values in near infrared wavelengths (NIR; $\lambda \sim 700-1300$ $\mathrm{nm}$ ) were observed for the early developmental stage (Tillering I), where biomass is low and reflectance is influenced mainly by soil. Maximum reflectance in the NIR was observed for the Jointing stage, which is coincident with highest values of green leaf area index, consequently low reflectance of solar radiation in red wavelengths and high scattering of solar radiation in NIR (Moreira et al., 1999). At Heading and Maturation stages, reflectance in visible (VIS; 350 - $700 \mathrm{~nm}$ ) and NIR regions increase and decrease, respectively, when compared to the previous growth stages, which is mainly caused by the increase of senescent leaves.

Correlation coefficients $(r)$ between each narrow-band and grain yield (Figure 3a) and plant height (Figure $3 b$ ) at different growth stages are presented in Figure 3. The pattern of $r$ curves for grain yield and plant height, at distinctive growth stages, were similar; although, $r$ in absolute values for plant height were smaller than those for grain yield. Lowest absolute $r$
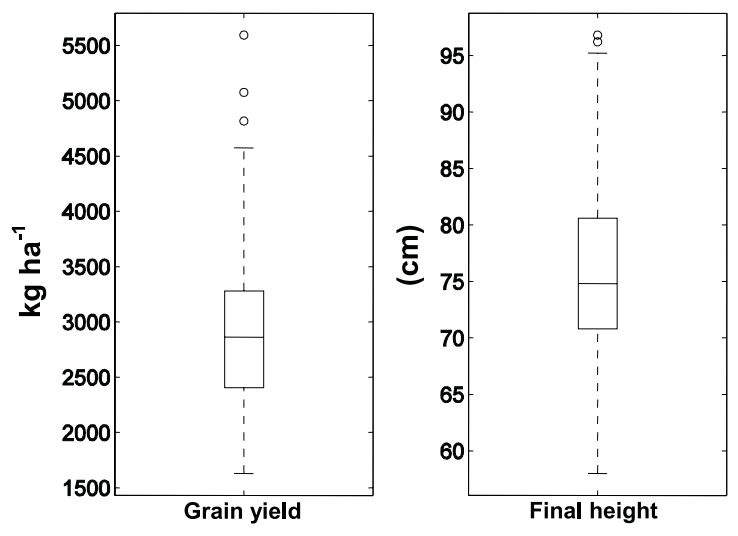

Figure 1 - Boxplot of grain yield and plant height for 80 plots.

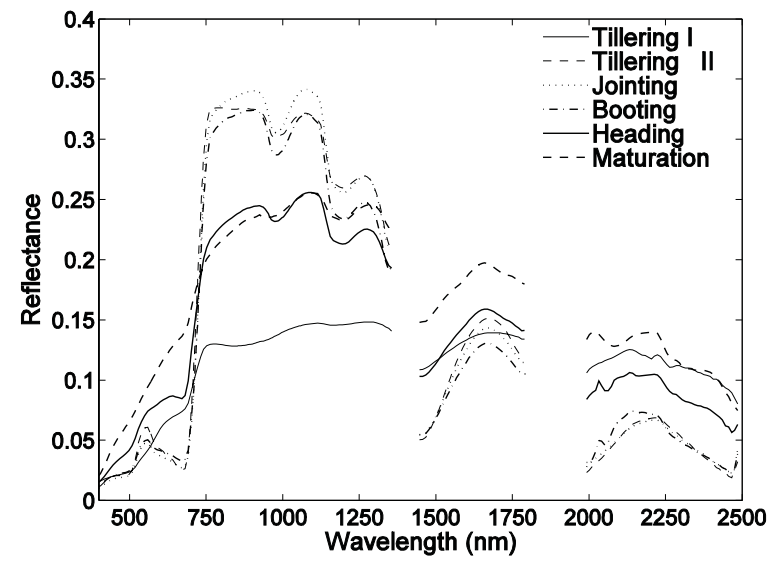

Figure 2 - Spectral reflectance characteristics of wheat at distinct growth stages. 
values were observed at Tillering I as a result of low crop development at this growth stage. Maximum negative values of $r$ were observed at Heading stage for grain yield, and at Booting stage for plant height in the $680 \mathrm{~nm}$ wavelength, which corresponds to high solar radiation absorption by chlorophyll pigments. For the red-edge region $(630-793 \mathrm{~nm})$, a high increase of $r$ values was observed, which is coincident with the reflectance increase of vegetation in this region (Figure 2 ). Greater positive $r$ values were recorded between 760$880 \mathrm{~nm}$ wavelengths. For grain yield, the maximum positive $r$ value observed was 0.72 at $902 \mathrm{~nm}$ during Booting stage. For plant height, the maximum positive $r$ value observed was 0.62 at $813 \mathrm{~nm}$ during Jointing stage. Similar results were also observed by Yang \& Chen (2004) for several biophysical parameters.

Table 2 presents the regression coefficients for the relationship between biophysical variables and OMNBR, NB_NDVI, and broad band VI (SR, NDVI and SAVI) at different growth stages. In general, greater $\mathrm{R}^{2}$ values were observed at full crop development during Booting and Heading stages, for all independent variables. On the other hand, lowest $\mathrm{R}^{2}$ values were observed at Tillering I and Maturation stages, when green biomass was low.
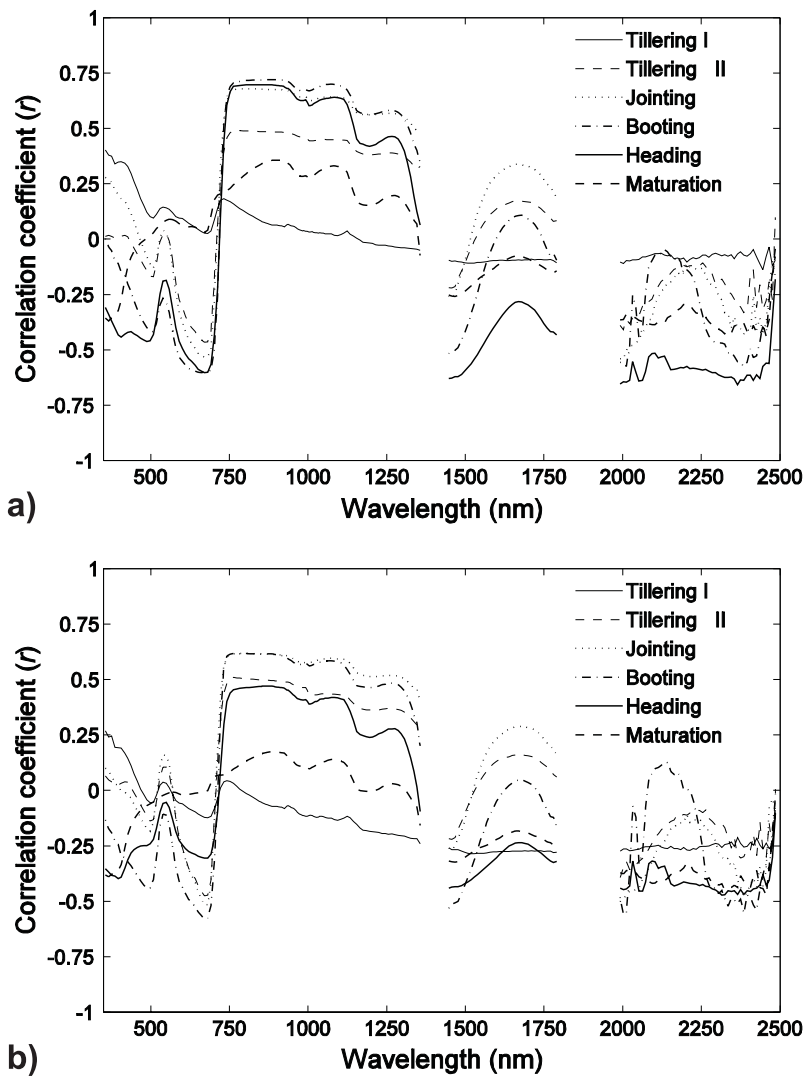

Figure 3 - Correlation coefficients between spectral reflectance of narrow-bands and: (a) grain yield; and (b) plant height for different growth stages.

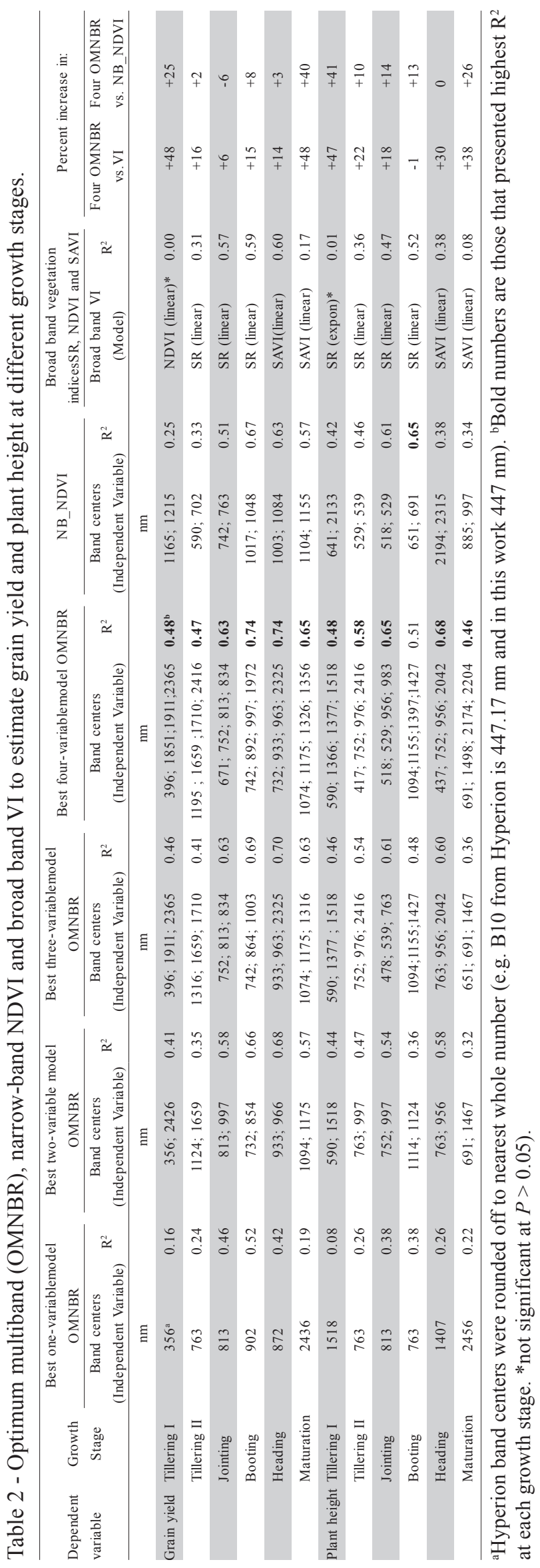


The OMNBR presented increased $\mathrm{R}^{2}$ values as the number of narrow-bands were added to the regression model. Best regression for grain yield $\left(R^{2}=0.74\right)$ and plant height $\left(R^{2}=0.68\right)$ were obtained with four narrow-bands at Heading stage. A significant increase in $\mathrm{R}^{2}$ values was observed for each new narrow-band incorporated in the model. For instance, at Booting stage $16 \%$ of wheat grain yield variation was explained with one narrow-band and up to $46 \%$ was explained with four narrow-bands. These results are in agreement with those obtained by Thenkabail et al. (2004) and Yang \& Chen (2004). The most frequent four-narrowbands in the OMNBR model were those from NIR $(\lambda$ $\sim 700 \mathrm{~nm}-1,300 \mathrm{~nm})$, followed by short wave infrared (SWIR; $\lambda \sim 1,300 \mathrm{~nm}-2,400 \mathrm{~nm})$ and VIS $(\lambda \sim$ $350 \mathrm{~nm}-700 \mathrm{~nm}$ ) indicating the relevance of the combined use of spectral bands from these three regions (NIR, SWIR, and VIS) for vegetation studies (Thenkabail et al., 2000; 2004).

The NB_NDVI index explained up to $67 \%$ of grain yield variation and up to $65 \%$ of plant height variation for Booting stage (Table 2). Best results were observed for bands in the NIR region for grain yield and in the VIS region for plant height.

Table 2 also presents the broad band VI and its relationship to both grain yield and plant height as well as the model type. Best overall $\mathrm{R}^{2}$ values, for grain yield and final plant height, during Jointing and Heading stages, were achieved with SR vegetation index

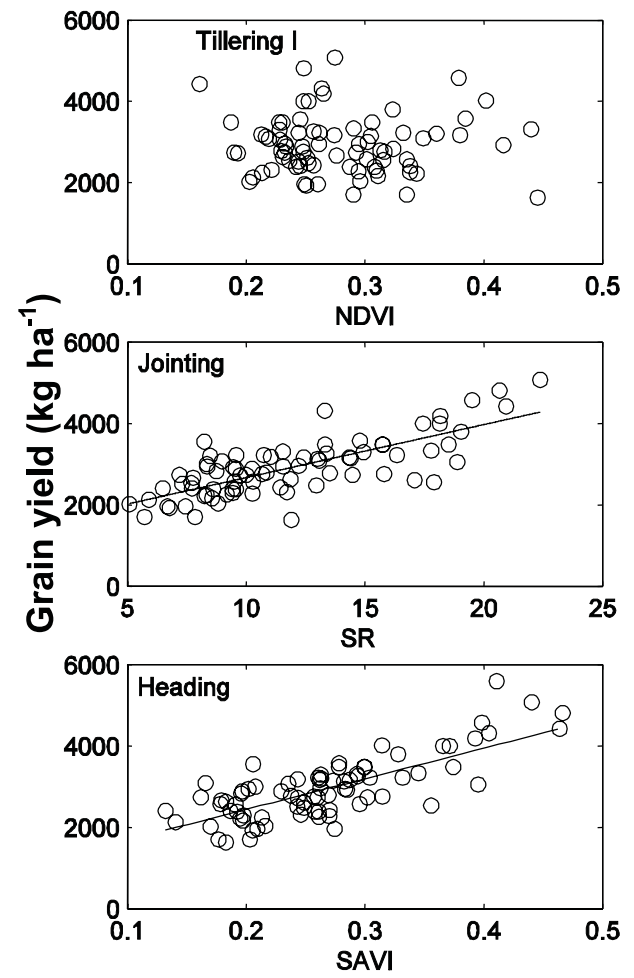

using the linear model. Best individual result for broad band VI was obtained for both SAVI $\left(\mathrm{R}^{2}=0.60\right)$ and $\mathrm{SR}\left(\mathrm{R}^{2}=0.59\right)$ to estimate grain yield during Heading and Booting stages, respectively. These results are in agreement with those reported by Tucker (1979), Turner et al. (1999), and Xavier \& Vettorazzi (2004), studying several other biophysical variables.

Figure 4 shows the scatter plots for the grain yield estimates provided by the broad band VI that yielded best $\mathrm{R}^{2}$ values in Table 2. Relationships were positive, as expected (Asrar et al., 1984). In theory, plants with higher production capacity should have higher LAI values and consequently higher VI values.

Figures $5 \mathrm{a}$ and $5 \mathrm{~b}$ present the reflectance spectra, during Heading stage, for the lowest $(1,629$ $\left.\mathrm{kg} \mathrm{ha}^{-1}\right)$ and highest $\left(5,593 \mathrm{~kg} \mathrm{ha}^{-1}\right)$ wheat grain yield plots, respectively. The less developed plants from the lowest grain yielding plot reflected more VIS solar radiation and scattered (reflected and transmitted) less NIR radiation (Figure 5a). In contrast, the highest grain yielding plot (Figure 5b) presented low VIS reflectance and high NIR reflectance, and affected differently the first- and second-order derivatives for the low and high grain yielding plots, as observed in Figure 5(c-f). The area to be integrated for the low grain plot is much smaller than the one for the high grain plot for both first (Figure $5 \mathrm{c}$, d; 1DZ_DGVI) and second-order derivative (Figure 5e, f; 2DZ_DGVI ).

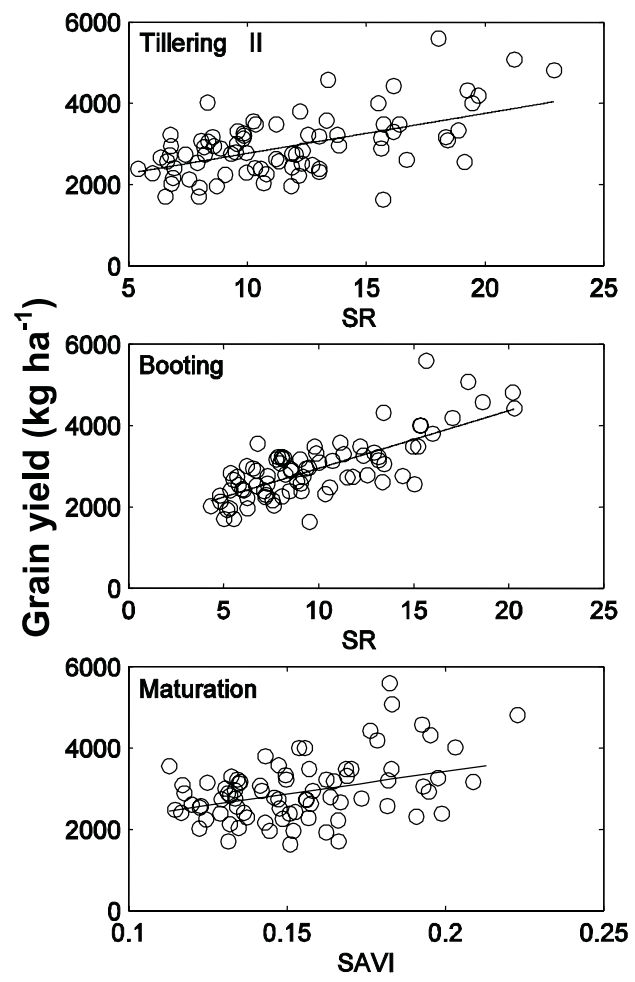

Figure 4 - Scatter plots between the best broad band VI and wheat grain yield at different growth stages. 


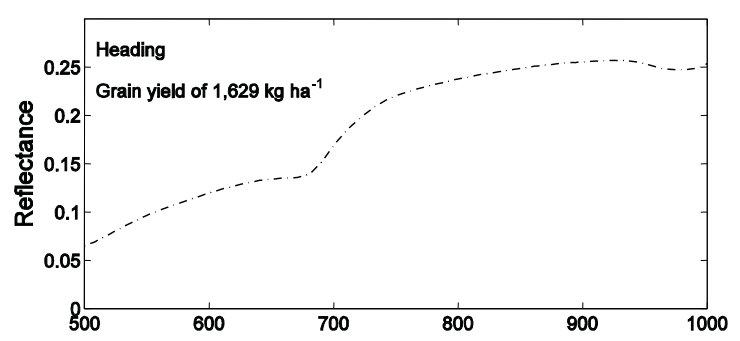

a)

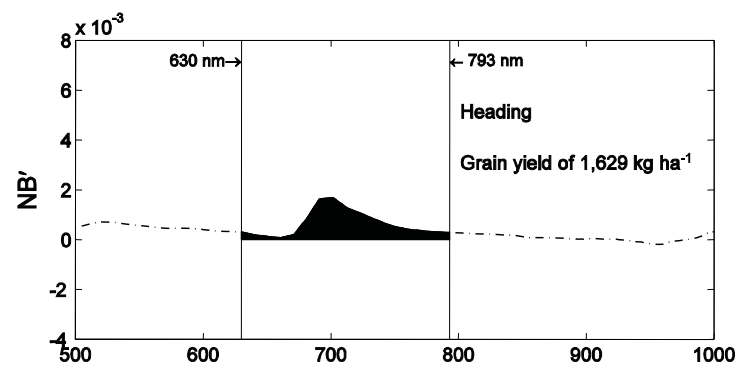

c)

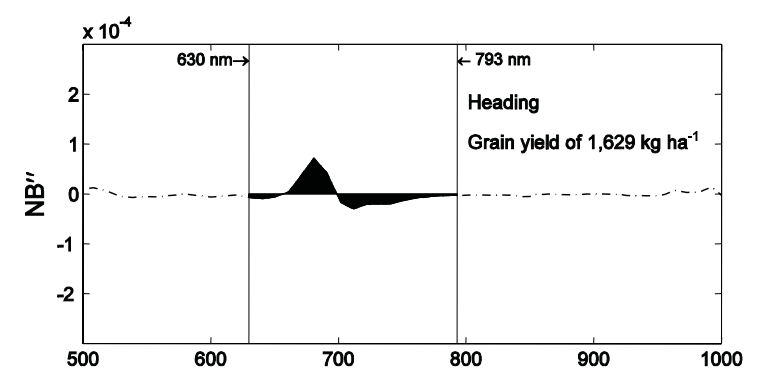

e)

Wavelength $(\mathrm{nm})$

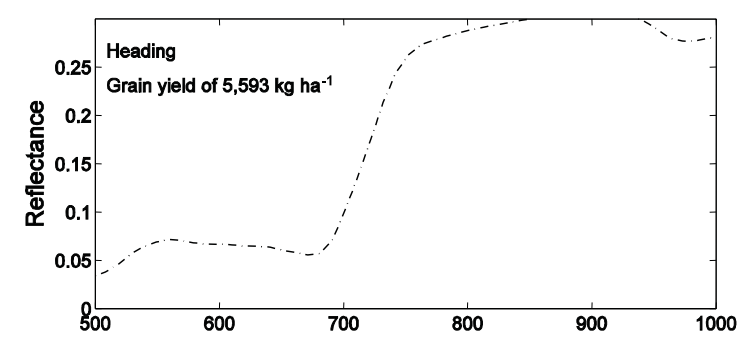

b)

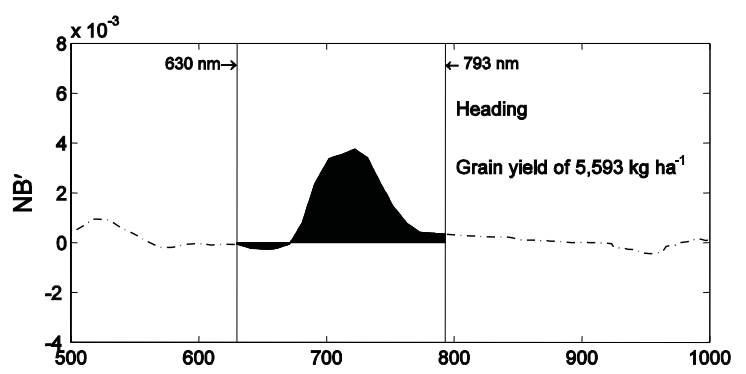

d) Wavelength $(\mathrm{nm})$

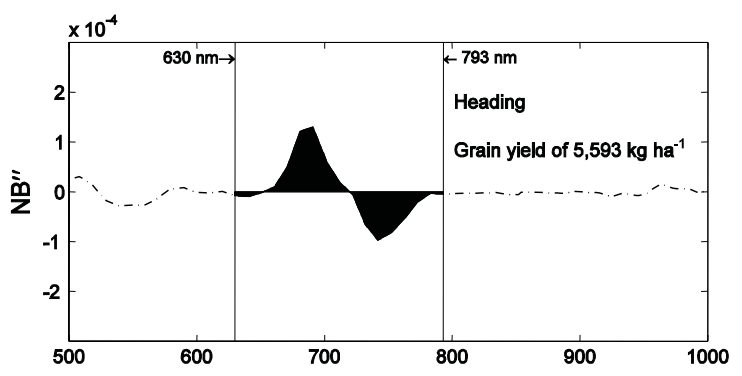

f)

Wavelength $(\mathrm{nm})$

Figure 5 - Spectral reflectance curve of plots with lowest (a) and highest (b) grain yield, respectively. First- (c, d) and second-order derivative (e, f) to generate 1DZ_DGVI and 2DZ_DGVI (integration from $630-793 \mathrm{~nm}$ ), respectively.

Table 3 - Results of first-order derivative, second-order derivative and derivative green vegetation indices to estimate grain yield and plant height at different wheat growth stages.

\begin{tabular}{|c|c|c|c|c|c|c|c|c|c|}
\hline \multirow{2}{*}{$\begin{array}{l}\text { Dependent } \\
\text { variable }\end{array}$} & \multirow{2}{*}{ Stage } & \multicolumn{2}{|c|}{$1^{\text {st }}$ order derivative } & \multicolumn{2}{|c|}{$2^{\text {nd }}$ order derivative } & \multicolumn{4}{|c|}{$\mathrm{R}^{2}$ values for derivative green vegetation indices } \\
\hline & & Band Center & $\mathrm{R}^{2}$ & Band Center & $\mathrm{R}^{2}$ & 1DL_DGVI & 1DZ_DGVI & 1DL_MDGVI & 2DZ_DGVI \\
\hline \multirow[t]{6}{*}{ Grain yield } & Tillering I & $1205^{\mathrm{a}}$ & $0.18^{b}$ & 852 & 0.16 & $0.01 *$ & $0.01 *$ & $0.01 *$ & $0.03 *$ \\
\hline & Tillering II & 1134 & 0.32 & 763 & 0.31 & 0.25 & 0.26 & 0.25 & 0.27 \\
\hline & Jointing & 943 & 0.58 & 773 & 0.57 & 0.47 & 0.49 & 0.47 & 0.48 \\
\hline & Booting & 1044 & 0.69 & 966 & 0.64 & 0.51 & 0.54 & 0.51 & 0.52 \\
\hline & Heading & 763 & 0.65 & 763 & 0.61 & 0.60 & 0.62 & 0.59 & 0.54 \\
\hline & Maturation & 1134 & 0.54 & 1155 & 0.52 & 0.10 & 0.17 & 0.09 & 0.07 \\
\hline \multirow[t]{6}{*}{ Plant height } & Tillering I & 966 & 0.25 & 793 & 0.27 & $0.01 *$ & $0.00 *$ & $0.02 *$ & $0.03 *$ \\
\hline & Tillering II & 915 & 0.38 & 763 & 0.31 & 0.27 & 0.27 & 0.27 & 0.29 \\
\hline & Jointing & 915 & 0.51 & 966 & 0.46 & 0.40 & 0.40 & 0.40 & 0.40 \\
\hline & Booting & 905 & 0.60 & 956 & 0.53 & 0.41 & 0.40 & 0.41 & 0.39 \\
\hline & Heading & 1124 & 0.35 & 882 & 0.40 & 0.21 & 0.24 & 0.21 & 0.19 \\
\hline & Maturation & 946 & 0.34 & 872 & 0.33 & $0.02 *$ & $0.05 *$ & $0.01 *$ & $0.01 *$ \\
\hline
\end{tabular}

${ }^{a}$ Hyperion band center was rounded off to nearest whole number. ${ }^{b}$ Bold numbers are those that presented highest $\mathrm{R}^{2}$ at each growth stage. *Not significant $(P>0.05)$. 
Table 3 shows $\mathrm{R}^{2}$ values for estimates of grain yield and plant height from first-order derivative of reflectance, second-order derivative of reflectance and derivative of green vegetation indices at different wheat growth stages. Greatest $\mathrm{R}^{2}$ values were obtained with the first-order derivative, but similar results were also achieved with the second-order derivative, both with bands from the NIR region. Best growth stages to estimate biophysical variables from spectral reflectance measurements were within Jointing and Heading stages.

Regression coefficients were similar among derivative green vegetation indices (1DL_DGVI, 1DZ_DGVI, 1DL_MDGVI and 2DZ_DGVI) with lower overall performance when compared to: first-order derivative, second-order derivative (Table 3 ) or even with broad band VI (Table 2).

Figure $6(\mathrm{a}, \mathrm{b})$ shows that in most cases both grain yield and plant height were better estimated from hyperspectral indices (OMNBR, NB_NDVI, first- and second-order derivative indices) than from

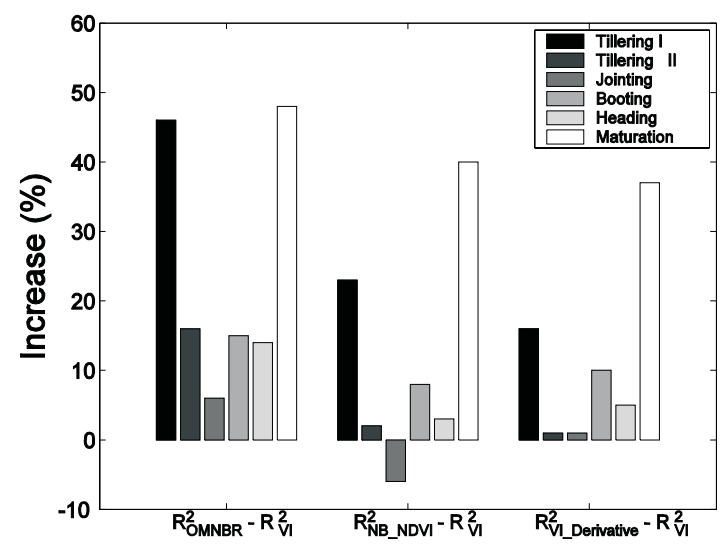

a) In relation to grain yield

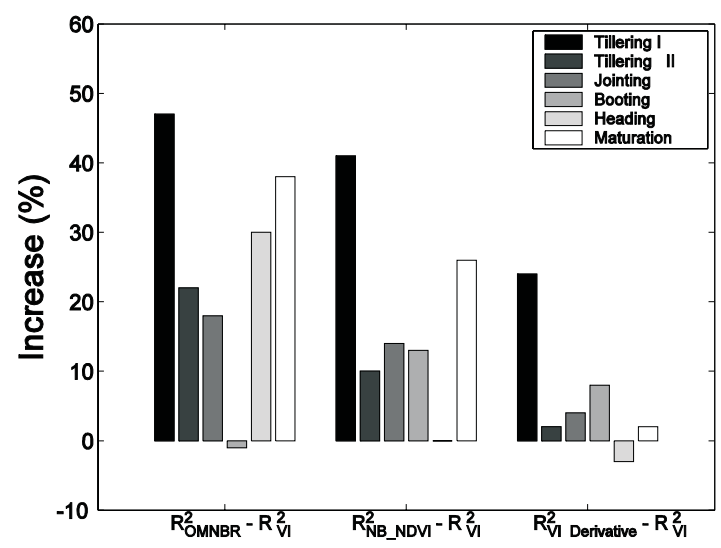

b) In relation to plant height

Figure 6 - Relative difference of $\mathrm{R}^{2}$ values between hyperspectral indices (OMNBR, NB_NDVI and derivative indices) and broad band vegetation indices (VI) for grain yield (a) and plant height (b). broad band indices. Major improvements of explained variance were observed early and late in the season. However, from Tillering II to Heading stages, when plants had a significant amount of green material, the broad band vegetation indices performed close to the narrow band VI, especially the NB_NDVI and the derivative indices. Among the hyperspectral indices, the OMNBR performed best in terms of $\mathrm{R}^{2}$ values (Figure 6).

Hyperspectral indices provided an overall better estimate of biophysical variables when compared to broad band VI. Major performance improvements with hyperspectral indices were observed early and late in the season when crop green leaf material was quite low. Among the several hyperspectral VI analyzed in this study the OMNBR with four bands presented highest $R^{2}$ values to estimate both grain yield $\left(R^{2}=74 \%\right.$ at Booting and Heading stages) and plant height $\left(\mathrm{R}^{2}=\right.$ $68 \%$ at Heading stage). Best results to estimate biophysical variables, independently of narrow or broad band VI, were observed for spectral measurements acquired between Tillering II and Heading stages. Broad band VI performed almost as well as narrow band VI derived from hyperspectral bands for wheat crop with significant amount of green material.

\section{REFERENCES}

ANALYTICAL SPECTRAL DEVICE INC. FieldSpec ${ }^{\circledR}$ FR Portable Spectroradiometer. 2003. Available in: <www.asdi.com/ asdi_t2_pr_sp_fsp.html>. Accesseed at: Feb. 14, 2003.

ASRAR, G.; FUCHS, M.; KANEMASU, E.T.; HATFIELD, J.L. Estimating absorbed photosynthetic radiation and leaf area index from spectral reflectance in wheat. Agronomy Journal, v.76, p.300-306, 1984.

BROGE, N.H.; LEBLANC, E. Comparing prediction power and stability of broadband and hyperspectral vegetation indices for estimation of green leaf area index and canopy chlorophyll density. Remote Sensing of Environment, v.76, p.156-172, 2001.

CARNEIRO, L.M.T.A.; BIAGI, J.D.; FREITAS, J.G.; CARNEIRO, M.C.; FELÍCIO, J.C. Diferentes épocas de colheita, secagem e armazenamento na qualidade de grãos de trigo comum e duro. Bragantia, v.64, p.127-137, 2005.

CHEN Z.; ELVIDGE, C.D.; GROENEVELD, D.P. Monitoring seasonal dynamics of arid land vegetation using AVIRIS data. Remote Sensing of the Environment, v.65, p.255-266, 1998.

DEMETRIADES-SHAH, T.; STEVEN, M.D.; CLARK, J.A. High resolution derivative spectra in remote sensing. Remote Sensing of Environment, v.33, p.55-64, 1990.

EARTH OBSERVATION-1. User Guide v. 2.3. Cincinnati: University of Cincinnati, 2003.

EARTH OBSERVATION SATELLITE COMPANY. User's guide for Landsat thematic mapper computer-compatible tapes. Cincinnati: Earth Observation Satellite Company, 1985.

ELVIDGE, C.D.; CHEN, Z. Comparison of broad-band and narrowband red and near-infrared vegetation indices. Remote Sensing of Environment, v.54, p.35-48, 1995.

GATES, D.M.; KEEGAN, J.H.; SCHLETER, J.C.; WEIDNER, V.R. Spectral properties of plants. Applied Optics, v.4, p.11-20, 1965.

HUETE, A.R. A soil-adjusted vegetation index (SAVI). Remote Sensing of Environment, v.25, p.295-309, 1988. 
JORDAN, C.F. Derivation of leaf-area index from quality of light on the forest floor. Ecology, v.50, p.663-666, 1969.

MATLAB-MATHWORKS. MATLAB 6.5 R13. Boston: MathWorks, 2002. (Software).

MOREIRA, M.A.; ANGULO FILHO, R.; RUDORFF, B.F.T. Radiation use efficiency and harvest index for wheat under drought stress at different growth stages. Scientia Agricola, v.56, p.597-603, 1999.

MOREIRA, M.A.; RUDORFF, B.F.T.; FELICIO, J.C.; FREITAS, J.G.; TARGA, M.S. Variação espectral e eficiência do uso da radiação fotossinteticamente ativa em ensaio com genótipos de trigo. Bragantia, v.64, p.331-338, 2005.

MYNENI, R.B.; MAGGION, S.; IAQUINTA, J.; PRIVETTE, J.L.; GOBRON, N.; PINTY, B.; KIMES, D.S.; VERSTRAETE, M.M.; WILLAMS, D.L. Optical remote sensing of vegetation: modeling, caveats, and algorithms. Remote Sensing of Environment, v.51, p.169-188, 1995.

ROUSE JR., J.W.; HAAS, R.H.; DEERING, D.W.; SCHELL, J.A.; HARLAN, J.C. Monitoring the vernal advancement and retrogration (green wave effect) of natural vegetation. Greenbelt: NASA, 1974. 371p. (NASA/GSFC type III final report).

SAS INSTITUTE. SAS/STAT users guide and software. Release 6.12. Cary: SAS Institute Inc, 1997.

THENKABAIL, P.S.; SMITH, R.B.; DE-PAUW, E. Hyperspectral vegetation indices for determining agricultural crop characteristics. Remote Sensing of the Environment, v.71, p.158-182, 2000.
THENKABAIL P.S.; ENCLONA E.A.; ASHTON M.S.; VAN DER MEER B. Accuracy assessments of hyperspectral waveband performance for vegetation analysis. Remote Sensing of Environment, v.91, p.354-376, 2004.

TUCKER, C.J. Red and photographic infrared linear combinations for monitoring vegetation. Remote Sensing of Environment, v.8, p.127$150,1979$.

TURNER, D.P.; COHEN, W.B.; KENNEDY, R.E.; FASSNACHT, K.S.; BRIGGS, J.M. Relationships between leaf area index and Landsat TM Spectral Vegetation Indices across three temperate zone sites. Remote Sensing of Environment, v.70, p.52-68, 1999.

YANG, C.-M.; CHEN, R.-K. Modeling rice growth with hyperspectral reflectance data. Crop Science, v.44, p.1283-1290, 2004.

XAVIER, A.C.; VETTORAZZI, C.A. Monitoring leaf area index at watershed level through NDVI from Landsat-7/ETM+ data. Scientia Agricola, v.61, p.243-252, 2004. Available in: $<$ http://www.scielo.br/ $\mathrm{pdf} / \mathrm{sa} / \mathrm{v} 61 \mathrm{n} 3 / \mathrm{a} 01 \mathrm{v} 61 \mathrm{n} 3 . \mathrm{pdf}>$. Accessed in: Jun. 01, 2005.

Received August 16, 2005

Accepted March 16, 2006 